\title{
ENNUMERATION OF WALL FLORAS OF MAHENDRANAGAR MUNICIPALITY, FAR WEST, NEPAL
}

\author{
Tilmaya Dhakal
}

Department of Botany, Siddhanath Science Campus, Tribhuvan University, Mahendranagar, Nepal

\begin{abstract}
Wall floras are the plants growing on the manmade habitats such as walls, fences, buildings, temples, old walls, etc. In this study, wall floras of Mahendranagar municipality were enumerated. A total of 111 species belonging to 87 genera and 33 families of angiosperm were found within the study area. All the types of plant species like herbs, shrubs and trees are reported and among them herbs are dominant. The major wall floras associated with different walls are Ficus bengalensis, Amaranthus spionus, Solanum nigrum, Adiantum sp, Dryopteris sp, mosses and some grasses.
\end{abstract}

Keywords: Habitats, herbs, shrubs, tree, wall flora.

\section{INTRODUCTION}

Walls are man-made habitats representing a specific environment which is partly similar to rocks and rock fissures (Woodell, 1979). Generally, the walls having cracks and crevices support the growth and development of diversity of plant species, ranging from algae to angiosperms. The study on wall flora of Mahendranagar municipality is not yet documented. Therefore, present study was carried out to enumerate the wall floras, which may serve as basic sources of data for further study on vegetation of walls in Nepal.

\section{MATERIALS AND METHODS}

\section{Study Site}

The present study was carried out in Mahendranagar Municipality, Far-Western region of Nepal. The site is located between $28^{\circ} 52^{\prime} \mathrm{N}$ to $29^{\circ} 8^{\prime} \mathrm{N}$ latitudes and $80^{\circ} 6^{\prime} \mathrm{E}$ to $80^{\circ} 14^{\prime} 5^{\prime \prime} \mathrm{E}$ longitude. The elevation ranges from $220 \mathrm{~m}$ to $270 \mathrm{~m}$ above sea level. The total area of Municipality is of $196.4 \mathrm{~km}^{2}$.

\section{Methodology}

The survey of wall flora was conducted in the different walls of Mahendranagar Municipality from May 2014 to April 2015 with the particular aim of assessing the relative frequency of different plants species on the various kinds of walls in the area. Fifty different walls were chosen with three criteria; firstly to cover the whole area of the Municipality, secondly types of walls and thirdly walls with relatively rich flora so as to enumerate the entire plants species colonizing the walls in the study area. The objectives of the study were to analyze the seasonal appearance of angiosperm flora on the walls of the present constructions of the municipality. The study area was divided into three sites i.e. site I, site II and site III.

The collection of wall flora was made from the different old walls (boundary walls, bridge walls, canals' walls, old houses' walls, dams' wall etc.) by random site visit method in all selected sites. Collected wall floras were identified with the help of relevant taxonomic literature, books, bulletins etc. The authentic identification 
of wall flora was done with the help of the deposited specimens of plant species at National Herbarium Godawari, Lalitpur (KATH). The floral citation carried out by annotated checklist of the flowering plants of Nepal (2000).

\section{RESULTS AND DISCUSSION}

In the present investigation, a total of 111 angiosperm species belonging to 39 families and 84 genera were found from Mahendranagar municipality. Out of 39 families, 36 families belong to class dicotyledonae and only 3 families belong to class monocotyledae. On the basis of habitat, 88 species are herbs, 7 species are shrubs, 14 species are tree and 2 species are climber (Fig. 1). Among them, Ficus species is very common in all the study sites. Aslan and Atamov (2006) also reported 113 species of wall flora on the stony walls in South east Turkey. Thapa (2015) observed a similar type of result, with 94 species belonging to 69 genera and 29 families on the walls of Bhimkalipatan, Pokhara. of the study, the dominant family was Poaceae (12 species), followed by Leguminaceae (9 species), Asteraceae ( 7 species) and rest of families have less than 5 species. Doljapavolva (2005) also found similar types of result on the wall of city of Plovdiv (Bulgaria). He reported Asteraceae (14 species), Fabaceae (13 species), Poaceae (12 species), Brassicaceae (8 species).

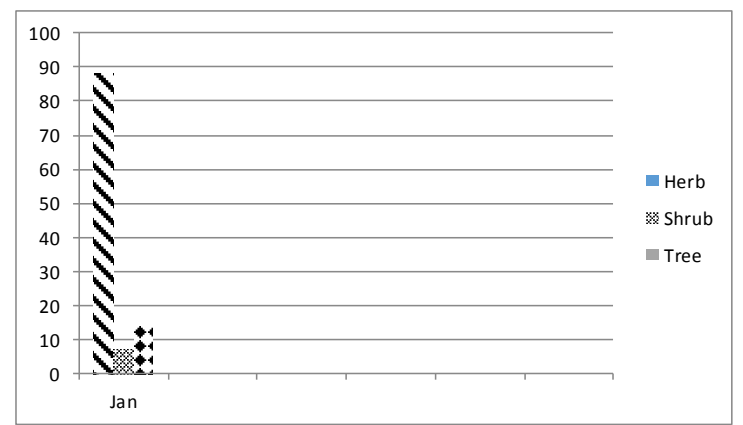

Fig.1. Habits of Plant Species

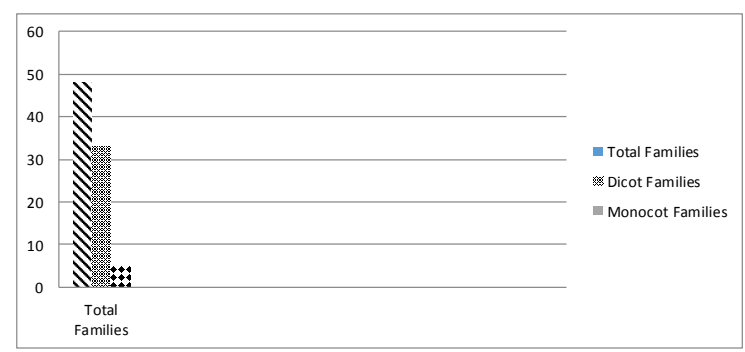

Fig. 2. Numbers of Families

Singh (2011) studied to analyze the seasonal vascular wall floristic composition of the Banaras Hindu University Campus, India. A total of 119 vascular wall floras were recorded, of which only one species was represented by Pteridophyte. No any species of Gymnosperm was observed as wall flora in the University Campus. Singh and Singh (2008) conducted a study to analyze the seasonal angiospermic wall floristic composition of city Buxar of state Bihar (India) covering the total land area of $24.7 \mathrm{~km}^{2}$. A total of 78 angiospermic wall floras were recorded. The angiospermic wall flora was represented by 64 genera belonging to 29 different families. Urban vascular flora and ecological characteristics of Kadikoy district, Istanbul, Turkey was studied by Etem et. al. (2008). In this study, different kinds of urban habitats within the boundaries of Kadikoy are described. A total of 561 vascular plant taxa were determined, wherein 412 (337 species, 44 subspecies and 31 varieties) were native and 149 (143 species and 6 varieties) were exotic and cultivated. 
Table 1: Wall floras of Mahendranagar Municipality

Class/Family/Genus and Species

Habit/life forms

I. MONOCOTYLEDONUS

1. Family: Commelinaceae

Commelina benghalensis L.

Herb

Commelina diffusa Burm

Herb

Commelina paludora Blume.

Herb

Cyanotis axillaris Schult.

Herb

Murdania nudiflora L.

Herb

2. Family: Cyperaceae

Cyperus difformis $\mathrm{L}$.

Herb

Cyperus esculentus $\mathrm{L}$.

Herb

Cyperus iria L.

Herb

Cyperus nutans Vahl, Enum.

Herb

Fimbristylis ovate (N.L. Burman), Kern

Herb

Schoenoplectus juncoides (Roxb.) Palla.

Herb

3. Family: Poaceae

Brachiaria ramosa (L.) Stapf

Herb

Cynodon dactylon (L.) Pers.

Herb

Dactyloctenium aegyptium Beauv.

Herb

Digitaria stricta Roth ex Roem. and Schult.

Herb

Eleusine indica (L.) Gaertn.

Herb

Eragrostis uniloides (Retz.) Nees exstend.

Herb

Eragrostis tenella (L.) P. Beauv

Herb

Echinochloa crusgalli (L.) P. Beauv

Herb

Imperata cylindrica $\mathrm{L}$.

Herb

Oplismenus burmannii Beauv.

Herb

Setaria virdis (L.) Beauv.

Herb

Saccharum spontaneum $\mathrm{L}$.

Herb

II. DICOTYLEDONS

1. Family: Acanthaceae

Rungia parviflora (Retz.)

Herb

Rungja repens (L.) Nees

Herb

Justicia adhatoda $\mathrm{L}$

Shrub 
2. Family: Amaranthaceae

Achyranthes aspera L.

Herb

Amaranthus spinosus L.

Herb

Amaranthus viridis L.

Herb

Amaranthus tricolor L.

Herb

Alternanthera sessili $\mathrm{R}$. Br.

Herb

3. Family: Anacardaceae

Spondias pinnara L

Tree

4. Family: Apocynaceae

Trachelosprmum lucidum (D. Don) K. Schum.

Woody climber

5. Family: Asclepiadaceae

Calotropis gigantea (L.) R. Br.

Shrub

Calotropis procera (Ait.) R. Br.

Shrub

6. Family: Asteraceae/compositae

Ageratum conyzoides L.

Herb

Yongja japonica (L.) Dc.

Herb

Gnaphalium affine D. Don

Herb

Sonchus asper (L.) Hill. Herb. Brit.

Herb

Sonchus oleraceae L.

Herb

Eclipta alba Hassk

Herb

Tegetus erecta L.

Herb

Tridax procumbens L.

Herb

Xanthium strumarium L.

Herb

7. Family: Cannabaceae

Cannabis sativa L.

Herb

8. Family: Caryophylaceae

Stellaria media var. procera Klatt and Richt.

Herb

9. Family: Chinopodiaceae

Chinopodium album L.

Herb

10. Family: Euphorbiaceae

Euphorbia hirta L.

Herb

Euphorbia prostate Aiton

Herb

Euphorbia parviflora L.

Herb 
Ricinus communis L.

Shrub

11. Family: Lamiaceae

Ocimum sanctum L.

Herb

Mentha spicata $\mathrm{L}$.

Herb

Pogostemon glaber Desf.

Herb

Pogostemon benghalensis (Burm. F.) Kunze

Herb

Colebrookea oppositifolia Sm.

Shrub

Elsholtzia blanda (Benth.) Benth.

Shrub

12. Family: Leguminosae

Acacia nilotica (L.) Delile

Tree

Cassia fistula $\mathrm{L}$.

Tree

Cassia tora L.

Tree

Lathyrus aphaca $\mathrm{L}$.

Herb

Mimosa pudica L.

Herb

Trifolium repens

Herb

Trifolium dubium Sibthorp

Herb

Trifolium alexandrium $\mathrm{L}$.

Herb

Trifolium pratense $\mathrm{L}$.

Herb

Medicago sativa $\mathrm{L}$.

Herb

Leucaeria leucoceph (Lam.) de Wit.

Herb

Alysicarpus vaginalis $\mathrm{L}$. DC

Herb

Dalbergia sissoo Roxb. ex DC

Tree

13. Family: Malvaceae

Bombax ceiba L.

Tree

Corchorus acutangulus L. Herb

Sida cordifolia Herb

Urena lobata $\mathrm{L}$. Herb

14. Family: Myrtaceae

Syzygium cumini (L.) Skeels.

Tree

15. Family: Meliaceae

Azadirachta indica A. Juss.

Tree

Melia azedarach L.

Tree

16. Family: Moraceae

Ficus benghalensis L.

Tree 
Ficus glomerata L. Tree

Ficus corica L. Tree

Ficus hispida L.F. Tree

Ficus religiosa $\mathrm{L}$ Tree

Morus alba L. Tree

17. Family: Nyctaginaceae

Boerhavia diffusa L. Herb

18. Family: Onagraceae

Desmodium trifolium (L.) DC Herb

19. Family: Oxalidaceae

Oxalis corniculata L. Herb

20. Family: Papavaraceae

Argemone mexicana L. Herb

Papaver dubium Koch Herb

21. Family: Phyllanthaceae

Phyllanthus urineria L. Herb

Phyllanthus varigata L. Tree

22. Family: Piperaceae

Peperomia pellucide (L.) Kunth. Tree

Piper longum L. Climber

23. Family: Plantaginaceae

Scoparia dulcis Linnaeus Tree

24. Family: Polygonaceae

Persicaria barbata (L.) Hara. Tree

Polygonum plebeium R. Br. Tree

25. Family: Primulaceae

Anagallis arvensis L. Tree

26. Family: Portulacaceae

Portulaca oleracea L. Tree

Portulaca quadrifida L. Tree

27. Family: Rhamnaceae

Ziziphus nummularia (Burm. f.) Wt. and Arn. Shrub

28. Family: Rubiaceae

Oldenlandia diffusa Roxb. Herb 
29. Family: Scrophulariaceae

Mecardonia procumhence Miller.

Herb

30. Family: Solanaceae

Datura metal L.

Shrub

Datura stramonium L.

Herb

Nicotiana plumbaginifolia Viv.

Herb

Solanum nigrum L.

Herb

Solanum virginianum $\mathrm{L}$.

Herb

31. Family: Tropaeolaceae

Tropaeolum majus L.

Herb

32. Family: Umbeliferae

Centella asiatica (L.) Urb.

Herb

33. Family: Verbenaceae

Lantana camara L.

Shrub

Lippa nodiflora Rich

Herb

Clerodendrum indicum (Linnaeus) Kuntze, Revis. Gen

Herb

\section{ACKNOWLEDEMENTS}

Author is thankful to Research Committee of Siddhanath Science Campus, for providing this invaluable opportunity, Prof. Dr. Purana Bhadur Chand Campus Chief Siddhanath Science Campus, Mahendranagar for providing financial support, Dr. Man Dev Bhatta, HOD, Botany for necessary facilities, Dr. Karbirsingh Khatri for identification of collected plant specimens.

\section{REFERENCES}

Aslan, M. and V. Atamov (2006): Flora and Vegetation of Stony Walls in South-east Turkey (Sanliurfa), Asian Journal of Plant Sciences, 5: 153-162.

Doljapavlova S. (2005): The wall flora of the NebetTepe. Architectural Reserve in the city of Plovdiv (Bulgaria).

Etem O., O. İbrahim, A. Volkan and S. Memduh (2008): Urban vascular flora and ecological characteristics of Kad1koy district, Istanbul, Turke, Maejo International Journal of
Science and Technology.

Singh, A. (2011): Observations on vascular wall flora of Banaras Hindu University Campus, India. Bullet. Environ. Pharmacol. and Life Sci. 1(1): 33-39.

Singh, D.K. and R. Singh (2008): Study of angiospermic wall floristic composition of city Buxar, (Bihar) India, Journal of pharmacognosy and phytochmistry.

Thapa, C.B. (2015): Wall flora of Bhimkali Patan, Pokhara, Nepal, Himalaya Biodiversity 3: 11-19.

Woodell, S. (1979): The flora of the walls and pavings. In Laurie, I. C. (Ed.) Nature in Cities, The Natural Environment in the Design and Development of Urban Green Space, John Wiley \& Sons Ltd., New York, pp. 135-157.

(Received 4 May 2017, revised accepted 26 July 2017) 